\title{
BLENDED LEARNING DALAM PENGEMBANGAN PEMBELAJARAN SUATU TUNTUTAN GUNA MEMPEROLEH KETERAMPILAN ABAD KE-21
}

\author{
Abdul Majir \\ Jurusan PGSD, FKIP, Universitas Katolik Indonesia Santu Paulus Ruteng. \\ Abdulmajir@gmail.com
}

\begin{abstract}
Abstrak
Pendidikan Indonesia abad ke-21, dihadapkan dengan sejumlah tantangan dan peluang. Tantangan pendidikan adalah penguasaan keterampilan siswa masih rendah. Sedangakan peluang mudah memperoh informasi, sumber belajar mudah diperoleh, hemat tenaga dan waktu. Tujuan penelitian untuk mengetahui secara mendalam blended learning dalam pengembangan pembelajaran dan mengetahui keterampilan yang seharusnya diperoleh siswa di madrasah satu atap (MIS, MTs dan MAS) Ar-Rahman Merombok kabupaten Manggarai Barat NTT dalam abad k-21. Jenis penelitian kualitatif dengan pendekatan multikasus. Teknik pengumpulan data menggunakan observasi, wawancara dan studi dokumentasi. Analisis data dilakukan dalam tiga tahapan yaitu reduksi data, penyajian data, dan verifikasi. Menguji keabsahan data menggunakan triangulasi sumber. Hasil penelitian menjadi kesimpulan: 1) blended learning: a) dapat memotivasi siswa untuk belajar lebih bersifat terbuka dan dua arah, b) siswa dan guru memperoleh keterampilan ganda, lebih disiplin waktu yaitu keterampilan berbahasa dan mengenal hard ware computer, c) siswa dan guru, mudah menyimpan dan membuka pembelajaran kapan, dimana saja. 2) Keterampilan Siswa a: kognitif (belajar mandiri dan tatap muka), afektif (disiplin waktu, menghargai teman, hubungan orang tua, siswa dan guru lebih harmonis), Psikomotor (mampu mengenal hardware computer), kemampuan mencari dan menemukan bahan belajar, mampu memecahkan masalah secara mandiri.
\end{abstract}

Kata Kunci: blended learning, pengembangan pembelajaran, keterampilan siswa

\section{PENDAHULUAN}

Abad ke-21 disebut sebagai abad persingan pengetahuan, ekonomi global, abad teknologi informasi, dan abad revolusi industri 4.0. Pada abad ini, terjadi perubahan yang sangat cepat dan sulit diprediksi dalam segala aspek kehidupan termasusk dunia pendidikan. Perubahan yang berlangsung sangat cepat ini dapat memberikan peluang jika dapat dimanfaatkan dengan baik dan memiliki kemampuan untuk menguasai, tetapi juga dapat menjadi persoalan jika tidak memiliki kemampuan untuk mengatasi berbagai perubahan tersebut. Saat ini lembaga pendidikan sedang bersaing untuk memenuhi kebutuhan pasar tenaga kerja dengan cara menghasilkan produk (siswa) yang berkualitas. Untuk mencapai 
pendidikan siswa berkualitas, tentu melalui proses yang baik. Semua orang sepakat untuk meningkatkan mutu pendidikan harus adanya perencanaan yang menjadi peranan penting dalam menentukan tingkat efektivitas pelaksanaan program. Masalah mutu pendidikan merupakan salah satu masalah nasional yang dihadapi dan mendapat perhatian serius dari pemerintah, masyarakat, dunia usaha dan dunia industri (DUDI) di Indonesia. Mengingat mutu pendidikan merupakan sumber dari kemajuan, dan kemakmuran bangsa.

Pendidikan merupakan barometer mutu kehidupan setiap orang di dunia. Jika kualitas pendidikan rendah, maka bisa dipastikan kehidupan masyakat juga rendah, begitupun sebaliknya. Oleh karena itu pendidikan dan pembelajaran harus rancang dan diatur sesuai kebutuhan masyarakat pengguna jasa pendidikan tersebut. Perubahan pendidikan dan pembelajaran hendaknya dilakukan secara menyeluruh baik formal maupun non formal. Dimana siswa pada semua jenjang harus mampu menguasai keterampilan agar mampu bersaing dalam hidup dan mampu melanjutkan ke jenjang yang lebih tinggi atau mencari pekerjaan. Salah satu contoh dari perubahan yang berdampak pada dunia pendidikan dan pembelajaran adalah semakin canggihnya teknologi informasi dankomunikasi, khususnya penggunaan Computer dan Handphone. Computer dan Handphone merupakan suatu tantangan dan peluang bagi dunia pendidikan. Pada era globalisasi saat ini, belajar bisa dilaksanakan dimana dan kapan saja, jika dimanfaatkan sebagai media pengembangan pembelajaran. Computer dan Handphone Android merupakan "perputakaan keliling"hampir semua masyarakat termasuk siswa dari sekolah dasar sampai perguuruan tinggi sudah memilikinya. Pendidikan dan pembelajaran tidak ada batasan jika jaringan internet berfungsi dengan baik. Faktor jarak, waktu, jumlah, kapasitas, kecepatan dan tatap muka, kini sudah bukan menjadi penghambat untuk melakukan kegiatan pembelajaran. Sehingga pantaslah jika keadaan ini disebut sebagai suatu revolusi pendidikan.

Kesamaan hak dalam memperoleh pendidikan bagi seluruh masyarakat benar-benar terwujud. Kegiatan belajar dan mengajar menjadi fleksibel, karena disesuaikan keadaan dan kemampuan setiap orang. Semua tidak terlepas dari fungsi sekolah, peran guru dan partisipasi masyarakat. Sebab ketiga komponen inilah dapat mempengaruhi kualitas masukan (input), proses (proces) dan keluaran 
(output) serta tujuan jangka panjang (outcome) sekolah. Sebuah sekolah dikatakan kualitas apabila dikelola secara profesional, memberi pelayanan terbaik pada siswa, memberikan kesempatan kepada siswa untuk mengembangkan potensi sesuai minat dan bakat secara seimbang, baik secara kognitif, afektif dan psikomotorik. Semua terangkum dalam kurikulum pembelajaran. Perubahan KTSP ke Kurikulum pembelajaran 2013 (K13), diyakini mampu mengakomodasi keterampilan abad ke-21 melalui proses pembelajaran, baik dilihat dari standar isi, standar proses, maupun standar penilaian. Pada standar proses, misalnya, guru diharuskan menerapkan pembelajaran dengan pendekatan saintifik. Kesemuanya terkait langsung dengan tekonologi, informasi dan komunikasi (TIK).

Namun kenyataanya masih banyak sekolah dan guru belum bisa memanfaatkan Computer dan Handphone android menjadi inovasi pembelajaran. Banyak faktor yang menjadi penyebab persoalan tersebut, seperti jaringan tidak lancar, belum bayak guru yang menguasai Computer, dan lain-lainya. Sama seperti yang terjadi di madrasah satu atap Ar-Rahman Merombok kabupaten Manggarai Barat NTT, mereka menggunakan Computer dan sebagian besar guru telah memiliki
Handphone android tetapi belum memaksimalkan penggunaan computer dan Handphone android dalam pembelajaran. Alasannya, hampir sama dengan sekolah-sekolah lain, jaringan tidak, belum bayak guru yang menguasai Computer. Padahal saat sekarang semua sistim pendidikan dan pembelajaran sekarang sudah menggunakan sistim online. Termasuk UN dan UAS sekarang berbasis Computer (online)

Berdasarkan uraian latar belakang di atas, maka peneliti tertarik untuk melakukan penelitian di madrasah satu atap (MIS, MTs dan MAS) ArRahman Merombok kabupaten Manggarai Barat NTT. Adapun fokus penelitian," Blended Learning Dalam Pengembangan Pembelajaran Suatu Tuntutan Guna Memperoleh Keterampilan Abad Ke-21". Tema ini menjadi teori utama (grand teory) penelitian. Adapun sub fokus (subtantive teory) penelitian yaitu: bagaimana penerapan blended learning dalam mengembangkan pembelajaran di Madrasah satu atap (MIS, MTs dan MAS) Ar-Rahman Merombok kabupaten Manggarai Barat? Bagaimana upaya guru agar siswa di madrasah satu atap (MIS, MTs dan MAS) Ar-Rahman Merombok kabupaten Manggarai Barat NTT memperoleh keterampilan abad 21? Peneliti berupaya mencari 
teori subtantif dari tema utama agar masalah utama bisa teratasi.

$\begin{array}{lcr}\begin{array}{l}\text { Penelitian } \\ \text { menjelaskan }\end{array} & \text { ini } & \text { bertujuan } \\ \text { blended } & \text { learning } & \text { mendalam } \\ & \text { dalam }\end{array}$
pengembangan pembelajaran dan menjelaskan secara holistik upaya guru di Madrasah satu atap (MIS, MTs dan MAS) Ar-Rahman Merombok kabupaten Manggarai Barat NTT agar siswa di memperoleh keterampilan abad ke-21 saat ini. Madrasah satu atap (MIS, MTs, dan MAS) Ar-Rahman Merombok Kabupaten Manggarai Barat NTT merupakan salah madrasah yang mampu bersaing dengan sekolah-sekolah lain, baik di kabupaten maupun propinsi di tengah persaingan abad ke-21 saat ini. Perkembangan jumlah siswa dari tahun ke tahun mengalami peningkatan, yaitu pada pada 3 tahun terahir 2017 sebanyak 210 siswa, tahun 2018 sebanyak 300 siswa dan tahun 2019 sebanyak 420 siswa. Di Madrasah satu atap (MIS, MTs, dan MAS) Ar-Rahman Merombok kabupaten Manggarai Barat NTT memiliki tenaga pengajar sebanyak 40 orang yang telah lulus S-1 dan mengajar sesuai dengan bidangnya, 1 kepala sekolah dengan berpendidikan S-1. Tenaga tata usaha berjumlah 3 orang berpendidikan S1, Pegawai perpustakaan 1 orang berbendidikan S1 serta tenaga khusus operator computer, 3 orang semua S1 computer. Dilihat dari kondisi ruang sarana dan prasarana, seperti ruang kelas yang berjumlah 12 ruang, 1 ruangan perputakaan, 1 musholah, ruang laboratorium Computer terintegrasi dengan ruang guru semua layak di pakai sebagai pendukung kegiatan proses pembelajaran.

Manajemen sekolah menggunakan manajemen berbasis sekolah (MBS). Sedangkan kurikulum yang digunakan adalah kurikulum 2013 yang diyakini mampu mengakomodasi keterampilan abad ke-21 melalui proses pembelajaran dengan pendekatan saintifik. Pembelajaran yang sebelumnya berpusat pada guru (teacher-centered) menjadi pembelajaran yang berpusat pada peserta didik (student centered). Dimana siswa berperan aktif untuk mengembangkan keterampilan yang sesuai potensi masing-masing.

Menurut Mason R. (1994) dalam Prasetya Citra Sukoco (2015:325) menjelaskan pendidikan mendatang akan lebih menentukan oleh jaringan informasi yang memungkinkan berinteraksi dan kolaborasi, bukan hanya gedung sekolah. Hal senada Tony bates (1995) menyatakan bahwa teknologi dapat meningkatkan kualitas dan jangkauan bila digunakan secara bijak untuk pendidikan dan latihan, dan mempunyai arti sangat 
penting bagi kesejahteraan ekonomi. Sehingga dalam abad 21 saat ini, pembelajaran yang relevan adalah pembelajaran yang menggabungkan antara pembelajaran konvensional dengan pembelajaran berbasis teknologi informasi dan komunikasi atau lebih dikenal dengan istilah Blended Learning, yaitu menggabungkan pembelajaran konvensional (hanya tatap muka) dengan pembelajaran dengan memanfaatkan teknologi informasi dan komunikasi. Melalui Blended Learning sistem pembelajaran menjadi lebih luwes dan tidak kaku. Istilah Blended Learning secara ketatabahasaan terdiri dari dua kata yaitu Blended dan Learning. Kata Blend berarti "campuran bersama untuk meningkatkan kualitas agar bertambah baik" (Collins Dictionary), atau formula suatu penyelarasan kombinasi atau perpaduan (Oxford English Dictionary) (Wendhie Prayitno, 2014: 3), sedangkan Learning memiliki makna umum yakni belajar, dengan demikian sepintas mengandung makna pola pembelajaran yang mengandung unsur pencampuran, atau penggabungan antara satu pola dengan pola yang lainnya. Elenena Mosa (2006) dalam Wendhie Prayitno, (2014: 4)) bahwa yang dicampurkan adalah dua unsur utama, yakni pembelajaran di kelas dengan tatap muka secara konvensional (classroom lesson) dengan pembelajaran secara online. Untuk lebih jelas penggabungan secara independen maupun secara kolaborasi, dengan menggunakan sarana prasarana teknologi informasi dan komunikasi dapat lihat pada gambar berikut.

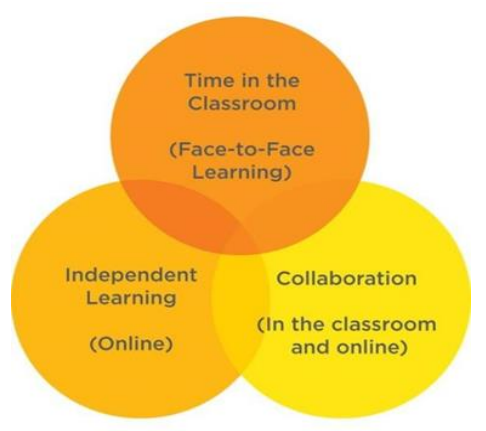

Gambar 1. Konsep Blended Learning, (Wendhie Prayitno, (2014: 7)

\section{METODE PENELITIAN}

Jenis penelitian ini adalah penelitian deskriptif kualitatif. Desain penelitian studi kasus lapangan. Karena meneliti kejadian yang bersifat deskriptif sebagai prosedur pemecahan masalah yang diselidiki, dengan menggambarkan atau melukiskan keadaan objek penelitian pada saat sekarang, berdasarkan faktafakta yang tampak atau apa adanya (Nasution,s, 2007:27. Penelitian ini dilaksanakan pada bulan April-Juli 2019 di Madrasah satu atap (MIS, MTs dan MAS) Ar-Rahman Merombok kabupaten Manggarai Barat NTT. Teknik pengumpulan data dengan menggunakan obsecasi, wawancara 
dan dokumentasi. Dalam penelitian kualitatif wawancara dilakukan secara bebas terkontrol artinya wawancara dilakukan secara bebas sehingga diperoleh data yang luas dan mendalam, tetapi masih memperhatikan fokus persoalanpersoalan yang diteliti dalam hal inilah pedoman wawancara digunakan. Proses wawancara dalam penelitian ini mengacu pada teori first order understanding dan second order undertsanding yaitu peneliti menginterpretasikan interpretasi dari informan tersebut sehingga menemukan makna baru yang akurat. Sedangkan observasi adalah mengamati secara mendalam pada sumber data, orang,tempat, kegiatan serta simbok-simbol yang mendukung. Adapun studi dokumentasi adalah analisi dokumen yang berkaitan, gambar, aturan atau kebijakan dan naskah- naskah yang terkait dengan blended learning di Madrasah satu atap (MIS, MTs dan MAS) Ar-Rahman Merombok kabupaten Manggarai Barat NTT. Kemudian dianalisis berdasarkan jenis penelitian kualitatif terdiri dari tiga komponen pokok yaitu reduksi data, sajian data, dan penarikan simpulan dengan verifikasinya. Untuk mengetahui keabsahan data menggunakan triangulasi sumber.

\section{HASIL PENELITIAN}

Berdasarkan hasil penelitian Blended Learning dalam pengembangan pembelajaran suatu tuntutan guna memperoleh keterampilan abad ke-21, 3 bagian, yaitu Blended Learning untuk tingkat madrasah ibtidaiyah (MI) kelas VI, Madrasah Tsanawiah (kelas VIII-IX) dan Madrasah Aliyah (X-XII). Blended learning yang terapkan di Madrasah satu atap (MIS, MTs dan MAS) ArRahman Merombok kabupaten Manggarai Barat NTT, yaitu: Model Web centric course. Model Web centric course adalah penggunaan Internet yang memadukan antara belajar jarak jauh dan tatap muka (konvensional). Sebagian materi disampaikan melalui internet, dan sebagian lagi melalui tatap muka, sedangkan fungsinya saling melengkapi. Model ini di yakini guru bisa memberikan petunjuk pada peserta didik untuk mempelajari materi pelajaran melalui web yang telah dibuatnya. Hal ini sesuai dengan teori Haughey (1998) dalam Prasetya Citra Sukoco ( 2014: 328-329) tentang pengembangan blended e-learning mengungkapkan bahwa terdapat tiga kemungkinan dalam pengembangan sistem pembelajaran berbasis internet, yaitu: web course adalah penggunaan internet untuk keperluan pendidikan, yang mana peserta didik dan pengajar sepenuhnya terpisah dan tidak diperlukan adanya tatap muka. Web 
centric course adalah penggunaan internet yang memadukan antar belajar jarak jauh dan tatap muka (konvesional). Model web enhanced course adalah pemanfaatan internet untuk menunjang peningkatan kualitas pembelajaran yang dilakukan di kelas.

Blended learning: Model Web centric course pada tingkat madrasah ibtidaiyah (MI) kelas VI, Madrasah Tsanawiah (kelas VIII-IX) dan Madrasah Aliyah (X-XII) di Madrasah satu atap (MIS, MTs dan MAS) ArRahman Merombok kabupaten Manggarai Barat NTT, dapat dikategori empat manfaat secara umum yaitu: (1) peserta didik dapat dengan mudah mengikuti mata pelajaran di kelas dan di rumah dengan membuka blog guru mata pelajaran. (2) siswa lebih disiplin waktu, (3) menghemat biaya, tenaga, mampu belajar secara kolaborasi dengan orangtuadi rumah, (4) hubungan komunikasi antara orangtua, guru dan siswa lebih harmonis dan tranparan. Pengembangan pembelajaran Blended learning: Model Web centric course di Madrasah satu atap (MIS, MTs dan MAS) Ar-Rahman Merombok kabupaten Manggarai Barat NTT adalah sekolah yang memberikan pelayanan terbaik dengan memberikan kesempatan kepada siswa secara seimbang baik secara kognitif, afektif dan psikomotorik, yang kesemuanya terangkum dalam kurikulum 2013 (K13)

Kompetensi Guru madrasah satu atap (MIS, MTs dan MAS) Ar-Rahman Merombok kabupaten Manggarai Barat NTT dalam mengembangakan pembelajaran yang relevan dengan perkembagan jaman dengan memanfaat Computer dan Handphone android, group wa, facebook, email. Menjadikan sekolah tersebut sekolah yang berkualitas dibanding dengan sekolah sejenis di lingkungannya.Tahapan Penerapan Blended Learning: Model Web centric course di sekolah di awali membuat rencana pelaksanaan pembelajaran (RPP) berdasarkan kompetensi dasar dalam kurikulum 2013 (K13). Kemudian menentukan platform teknologi yang akan digunakan dalam pembelajaran tanpa melaksanakan tatap muka, seperti Platform Group Miling List, group wa, facebook, blog guru). Selanjutnya, bagaimana platform-platform yang sudah ditentukan oleh guru diterapkan dalam pembelajaran dengan tahapan seperti pada tabel berikut. 
Tabel 1. Tahapan tatap muka Blended Learning: Model Web centric course

\begin{tabular}{|c|c|c|c|}
\hline No & $\begin{array}{l}\text { Aktivitas } \\
\text { Pembelajaran }\end{array}$ & $\begin{array}{l}\text { Waktu } \\
\text { Pelaksanaan }\end{array}$ & $\begin{array}{l}\text { Platfor } \\
\text { m }\end{array}$ \\
\hline \multirow[t]{4}{*}{1} & Pendahuluan & & \\
\hline & $\begin{array}{l}\text { a. Guru } \\
\text { memberikan } \\
\text { memberikan } \\
\text { tugas kepada } \\
\text { siswa untuk } \\
\text { membaca } \\
\text { materi } \\
\text { pelajaran dan } \\
\text { menjawab } \\
\text { beberapa } \\
\text { pertanyaan } \\
\text { awal yang ada } \\
\text { di Blog Guru }\end{array}$ & \multirow[t]{2}{*}{$\begin{array}{l}\text { Sebelum } \\
\text { pelaksanaan } \\
\text { pembelajaran } \\
\text { di kelas }\end{array}$} & \multirow[t]{2}{*}{\begin{tabular}{|l} 
Blog \\
Guru : \\
akida \\
h.blog \\
spot.c \\
om
\end{tabular}} \\
\hline & $\begin{array}{l}\text { b. Siswa } \\
\text { mengakses } \\
\text { Blog guru, } \\
\text { selanjutnya } \\
\text { membaca dan } \\
\text { mengerjakan } \\
\text { beberapa } \\
\text { pertanyaan } \\
\text { guru. }\end{array}$ & & \\
\hline & $\begin{array}{l}\text { c. Guru } \\
\text { memberikan } \\
\text { jadwal untuk } \\
\text { melakukan } \\
\text { diskusi dari } \\
\text { hasil jawaban } \\
\text { siswa } \\
\text { terhadap } \\
\text { beberapa } \\
\text { pertanyaan } \\
\text { guru melalui } \\
\text { Blog Siswa }\end{array}$ & $\begin{array}{l}\text { Sebelum } \\
\text { pelaksanaan } \\
\text { pembelajaran } \\
\text { di kelas } \\
\text { dengan } \\
\text { jadwal yang } \\
\text { telah } \\
\text { ditentukan } \\
\text { sebelumnya }\end{array}$ & $\begin{array}{l}\text { Group } \\
\text { Facebook } \\
\text { : www. } \\
\text { facebook. } \\
\text { com }\end{array}$ \\
\hline & $\begin{array}{l}\text { d Guru } \\
\text {. menyampaika } \\
\text { n kompetensi } \\
\text { Dasar, dan } \\
\text { Tujuan } \\
\text { Pembelajaran }\end{array}$ & $\begin{array}{l}\text { Pertemuan } 1 \\
(2 \times 40 \text { menit }) \\
\text { (tatap muka) } \\
(10 \text { menit })\end{array}$ & \\
\hline
\end{tabular}

\begin{tabular}{|c|c|c|c|}
\hline \multirow[t]{2}{*}{2} & $\begin{array}{l}\text { Kegiatan Inti } \\
\text { a Siswa } \\
\text { mempresenta } \\
\text { sikan hasil } \\
\text { diskusi } \\
\text { sebelumnya } \\
\text { dengan } \\
\text { menayangka } \\
\text { n Blog Siswa }\end{array}$ & 30 menit & $\begin{array}{l}\text { Blog } \\
\text { Siswa }\end{array}$ \\
\hline & $\begin{array}{ll}\text { b } & \text { Siswa } \\
\text {. } & \text { diminta } \\
\text { membuat } \\
\text { artikel hasil } \\
\text { diskusi dan } \\
\text { presentasi } \\
\text { yang } \\
\text { dipublikasika } \\
\text { n ke dalam } \\
\text { web sekolah }\end{array}$ & 30 menit & Blog guru \\
\hline \multirow[t]{3}{*}{3} & Penutup & & \\
\hline & $\begin{array}{ll}\text { a } & \text { Guru } \\
\text { · mengajak } \\
\text { siswa untuk } \\
\text { menyimpulka } \\
\text { n bersama }\end{array}$ & \multirow[t]{2}{*}{10 menit } & \multirow[t]{2}{*}{$\begin{array}{l}\text { Blog } \\
\text { Guru: } \\
\text { Akidah.bl } \\
\text { ogspot.co } \\
\text { m }\end{array}$} \\
\hline & $\begin{array}{ll}\mathrm{b} & \text { Guru } \\
. & \text { memberikan } \\
& \text { tugas } \\
& \text { selanjutnya } \\
& \text { melalui Blog } \\
& \text { Guru }\end{array}$ & & \\
\hline
\end{tabular}

Berdasarkan langkah-langkah pembelajaran di atas, maka guru di Madrasah satu atap (MIS, MTs dan MAS) Ar-Rahman Merombok kabupaten Manggarai Barat NTT telah memenuhi karakteristik pembelajajara Blended Learning. Guru telak mengaktifkan siswa dalam memahami materi pelajaran yang di-upload guru dalam Web Blog Guru. Selain itu juga, guru mengaktifkan peserta didik 
untuk berdiskusi dari hasil tugas yang dikerjakan peserta didik melalui sosial media facebook. Hal ini sesuai dengan teori belajar konstruktivisme sosial yang dikembangkan oleh Vygotsky. Menurut Vigotsky (1978) adalah sebagai berikut: the way learners construct knowledge, think, reason, and reflect on is uniquely shaped by their relationship with other. He argued that the guidance given by more capable other, allows the learner to engage is levels of activity that could not be managed alone. Konstruktivisme sosial disebut juga collaborative learningSedangkan karakteris teori belajar, siswa membangun pengetahuan, berfikir, mencari alasan, dan dicerminkan dengan bentuk yang unik melalui berhubungan dengan yang lain. Bentuk tugas yang diolah dan pengetahuan dinilai dan diciptakan lalu membangun pengetahuan yang baru (Kokasih. A. L. 2010: 44).

\section{Upaya Guru Agar Siswa Memperoleh Keterampilan Abad 21}

Kunci kesuksesan Madrasah satu atap (MIS, MTs dan MAS) Ar-Rahman Merombok kabupaten Manggarai Barat NTT adalah kepala sekolah, guru dan staf, memberikan pelayanan terbaik kepada siswanya dengan memberikan kesempatan kepada siswanya untuk mengembangkan potensi dirinya sesuai minat dan bakat yang dimiliki secara seimbang. Dalam bidang kognitif, sekolah menyediakan buku-buku pembelajaran yang relevan sesuai jenjang masing-masing siswa. Selain buku buku pelajaran, sekolah menyediakan perpustakaan sekolah. Dalam bidang afektik, sekolah menyediakan musholah sekolah. Di musholah ini, siswa, guru, kepala sekolah, dan staf melakukan kegiatan untuk membektuk prilaku siswa. Seperti: setiap pagi sebelumpelajaran dimulai, semua siswa sholat Dhuha, sholat 5 waktu dan latihan ceramah serta mengaji. Dalam Bidang psikomotor, sekolah selalu melakukan kegiatan membuat perhiasan dari limbah sampah masyarakat sekitar, melatih tali grafi, pot bunga, dan lomba desain gambar, lomba pidato bahasa arab dan bahasa Inggris.

Pada abad ke-21 saat ini, pendidikan yang bermutu harus mencakup dua orientasi yakni orientasi akademis yang menitik beratkan pada peserta didik, dan orientasi ketrampilan hidup (Life Skills). Teori Lim D. H, Morris M. L dan Kupritz V. W, (2005:18) menjelaskan penggabungan aspek blended e-learning yang termasuk web-based instruction, streaming video, audio, synchronous and asychronous communication atau aspek terbaik pada aplikasi teknologi informasi blended elearning, dengan kegiatan tatap muka, 
termasuk metode mengajar, teori belajar dan dimensi pedagogik. Hal senada dikemukakan Anderson \& Krathwohl, (2001) dalam Jufri, Wahab A. (2010: 90-92), dimensi poses pengetahuan terbagi dalam tiga yaitu kognitif, afektif dan psikomotor. Ranah kognitif terbagi dalam enam tingkat yaitu : 1) mengingat (remember): mengambil, mengakui, dan mengingat pengetahuan yang relevan dari memori jangka panjang; 2) memahami (understand): membangun makna dari lisan, pesan tertulis, dan grafis melalui menafsirkan, mencontohkan, mengklasifikasi, meringkas, menyimpulkan, membandingkan, dan menjelaskan; 3) menerapkan (apply): melaksanakan atau menggunakan prosedur melalui pelaksana, atau menerapkan; 4) menganalisis (analyze): menyusun materi menjadi bagianbagian utama, menentukan bagaimana bagian-bagian berhubungan satu sama lain dan yang secara keseluruhan struktur atau tujuan melalui membedakan, mengorganisasikan, dan menghubungkan; 5) evaluasi (evaluate): membuat penilaian berdasarkan kriteria dan standar melalui memeriksa dan mengkritisi; dan 6) menciptakan (create): menempatkan elemen bersama-sama untuk membentuk suatu kesatuan yang utuh atau fungsional, reorganisasi elemen ke pola baru atau struktur melalui menghasilkan, perencanaan, atau menghasilkan.

Sedangkan menurut Drost (2000) dalam Wayan Redhana, (2019: 2245) mengemukakan Secara lebih spesifik, beberapa dimensi kemampuan peserta didik yang perlu diperhatikan dalam upaya pemberdayaan individu peserta didik melalui proses belajar ini adalah: a) Mengetahui kekuatan dan keterbatasan diri, b) Meningkatkan rasa percaya diri, c) Dapat meningkatkan kemampuan menghargai diri dan orang lain, d) Meningkatkan kemandirian dan inisiatif untuk memulai perubahan, e) Meningkatkan komitmen, tanggung jawab dan motivasi internal, f) Meningkatkan kemampuan mengatasi masalah secara kreatif danpositif, g) Meningkatkan kemampuan untuk melaksanakan tugas secara professional, h) Mengembangkan kemampuan mengendalikan diri dan tidak mudah menyalahkan orang lain, i) Meningkatkan kemampuan membina hubungan interpersonal yang baik, j) Meningkatkan kemampuan beradaptasi dengan lingkungan.

Menurut UNESCO, (Auliya Miftachul Umri, 2013: 3-4) melalui international commission on euication for the $21^{\prime \prime}$ century yang antara lain bertujuan untuk mengubah dunia "from technologically divided world 
where high technology is privilage of the few to technologically united world" dengan mengusulkan empat pilar pendidikan yakni belajar untuk mengetahui (learning to know), belajar untuk melakukan (learning to do), belajar untuk menjadi learning to be), dan belajar untuk hidup bersamasama atau belajar bersosialisasi (learning to live together). Kemampuan guru untuk menerapkan empat pilar pendidikan atau pilar belajar tersebut berarti bahwa proses pembelajaran memungkinkan peserta didik untuk menguasai cara memperoleh pengetahuan, berkesempatan berinteraksi secara aktif sesama peserta didik sehingga dapat mengembangkan potensi diri dan menemukan jati dirinya. Model pembelajaran seperti ini hanya dapat berlangsung dengan difasilitasi oleh guru yang penuh konsentrasi, peralatan yang memadai, materi yang terpilih dan waktu yang cukup secara fleksibel.

Dengan demikian blended learning dapat diterapkan tergantung kemampuan guru, kreavitas dan inonasi dalam pembelajaran. Hal ini sesuai amanat Undang-undang Nomor 14 Tahun 2015 tentang guru dan dasen pasal (8) menyebutkan guru dan dosen wajib memiliki kualifikasi akademik, kompetensi, sertifikasi akademik, sehat jasmani dan rohani serta memiliki kemampuan untuk mewujudkan tujuan pendidkan nasional. Penerapan Undang-undang Nomor 14 Tahun 2015 tentang guru dan dasen pasal (8) ini bukanlah suatu hal yang mudah, sebab guru akan dituntut untuk mampu melaksanakan pekerjaannya baik secara mandiri maupun secara kolaboratif harus berlandaskan sikap ikhlas. Ikhlas dalam hal ini dimaksudkan sebagai sikap seseorang guru yang bekerja secara sungguh-sungguh dan bersedia mengembangkan paradigma berpikir dan bertindak yang sesuai dengan kebutuhan siswa dan lingkungan hidupnya.

Prinsip dan proses pembelajaran pada semua jenjang, pendidikan dasar sampai perguruan tinggi menekankan pada active learning, creative learning, effective learning. Terkait dengan cara penyimpanan dan pencarian informasi dengan teknologi komputer menjadi hal yang sangat penting dalam dunia pendidikan dan pembelajaran. Internet merupakan sumber belajar yang sangat potensial untuk menghubungkan siswa dengan beragam sumber belajar dibutuhkan. Hal ini berimplikasi pada guru untuk meredefinisi pengetahuan dan keterampilannya tentang persiapan, pelaksanaan, instrument dan strategi asesmen dalam pembelajaran. Guru harus selangkah lebih maju dari siswa 
menguasai keterampilan abad ke-21 yang diistilahkan 4C: keterampin dalam komunikasi (Communication), kolaborasi (Collaboration), berpikir kritis dan pemecahan masalah (Critical Thinking and Problem Solving), dan Kreativitas dan inovasi (Creativity and Innovation) (Leen, C.C., Hong, dkk. 2014: 254). Menurut Tony Wagner (2008) dalam Ramdhani, M.R., Usodo, B., dan Subanti, S, (2017: 2245) menjelaskan keterampilan abad ke-21 bagi siswa membutuhkan tujuh keterampilan agar dapat bertahan hidup yaitu: a) berpikir kritis dan pemecahan masalah, b) kolaborasi dan kepemimpinan, c) kelincahan dan kemampuan beradaptasi, d) inisiatif dan wirausaha, e) komunikasi lisan dan tertulis yang efektif, f) mengakses dan menganalisis informasi, g) rasa ingin tahu dan imajinasi.

Dalam Konsorsium beberapa negara yaitu Australia, Finlandia, Portugal, Singapura, Inggris, dan Amerika, mendefinisikan keterampilan abad 21 yaitu: pengetahuan, sikap, nilai, dan etika (The Partnership for 21st Century Skills, 2008) Adapun yang termasuk kategori keterampilan abad 21 yaitu: a) Cara berpikir yang meliputi: kreativitas dan inovasi, berpikir kritis, memecahkan masalah, pengambilan keputusan, dan belajar untuk belajar (metakognisi ), b) Cara Kerja berkaitan dengan: komunikasi dan kerja sama tim, c) Alat untuk Kerja berupa: pengetahuan umum, teknologi informasi dan komunikasi ( TIK ) dan keaksaraan, d) Hidup di dunia yang meliputi: kehidupan bernegara, kehidupan dan karir, tanggung jawab pribadi dan sosial, termasuk kesadaran budaya dan kompetensi (Uno, B. Hamzah. 2011: 70-74)

Berdasarkan uraian di atas, maka kegiatan pembelajaran siswa di sekolah harus variatif tidak monoton dan memanfaakan teknologi secara seimbang untuk memperoleh keterampilan, semestinya diperoleh setiap siswa melalui pembelajaran pada setiap jenjang pendidikan:

Pertama komunikasi (communication): guru dituntut untuk dapat mengembangkan suasana yang dapat memberikan kesempatan seluasluasnya bagi setiap siswa berkomunikasi dan mempertanyakan berbagai hal yang berkaitan dengan pengembangan potensi dirinya. Hal ini menjadi sangat penting karena pendidik adalah juga pemimpin yang harus mengakomodasi berbagai pertanyaan dan kebutuhan siswa. guru maupun siswa harus berusaha saling menghargai dan menghormati pendapat dan pandangan masingmasing. Suasana kesetaraan perlu di kembangkan dengan berorientasi pada upaya mendorong siswa agar mampu 
berkomunikasi di antara sesamanya secara harmonis dan rasional. Supaya komunikasi antar siswa terjalin secara efektif dibutuhkan teknik berkomunikasi yang tepat, baik tulisan maupun lisan atau menggunakan media.

Kedua kolaborasi (Collaborative) adalah kemampuan berkolaborasi atau bekerja sama, saling bersinergi, beradaptasi dalam berbagai peran dan tanggungjawab; bekerja secara produktif dengan yang lain; menempatkan empati pada tempatnya; menghormati perspektif berbeda. Dalam pembelajaran seorang guru memberi mampu memberi contoh dalam menjalankan tanggung jawab sebagai pengajar dan pendidik, baik di sekolah, maupun di lingkungan masyarakat. Menghubungkan ilmu dengan dunia nyata dilakukan dengan mengajak siswa melihat kehidupan dalam dunia nyata. Memaknai setiap materi ajar terhadap penerapan dalam kehidupan penting untuk mendorong motivasi belajar siswa.

Ketiga berpikir kritis dan pemecahan masalah (Critical thinking and Problem Solving) adalah kemampuan untuk memahami sebuah masalah yang rumit, mengkoneksikan informasi satu dengan informasi lain, sehingga akhirnya muncul berbagai perspektif, dan menemukan solusi dari suatu permasalahan. Guru dituntut menyampaikan materi ajar yang menantang, yang membuat siswa untuk menalar, memahami dan membuat pilihan yang rumit; memahami interkoneksi antara sistem, menyusun, mengungkapkan, menganalisis, dan menyelesaikan masalah. Sehingga pembelajaran bermakna sebagai proses pemberdayaan kemampuan berfikir kritis dan kemampuan menyelesaikan masalah.

Keempat kreativitas dan inovasi (creativity and Innovation) adalah kemampuan untuk mengembangkan, melaksanakan, dan menyampaikan gagasan-gagasan baru kepada yang lain; bersikap terbuka dan responsif terhadap perspektif baru dan berbeda. Guru dalam menyampaikan materi pembelajaran, harus mampu menggabungkan antara terori praktek dengan media seperti computer atau bahan alam yang ekonomis sehingga bisa menghasilkan penemuanpenemuan baru bernilai secara ekonomis atau mengahsil ilmu baru yang sering disebut ilmiah.

Pada standar proses, misalnya, guru diharuskan menerapkan pembelajaran dengan pendekatan saintifik. Model pembelajaran yang berpusat pada peserta didik (student-centered) lebih diutamakan. Dengan demikian siswa dapat mengembangkan potensi dan 
upaya mengembangkan keterampilan mereka miliki.

\section{SIMPULAN}

Berdasarkan hasil penelitian dan pembahasan Blended Learning Model Web centric course sangat relevan digunakan untuk tingkat MI, MTs dan MAS atau sekolah menengah atau sederajat.

Pembelajaran campuran (blended learning) dengan memanfaatkan unsur teknologi informasi, dengan pola bimbingan langsung dari guru bermanfaat memotiasi siswa dan guru untuk mempelajari pengetahuan baru (learn how to learn); meningkatkan pengetahuan dan keterampilan guru dan siswa. Penerapan Blended learning dengan memanfaatkan berbagai macam media dan technologi computer dan Handphone, yang benar harus mampu mengakomodir 6 (enam) unsur, yaitu: (1) tatap muka (2) belajar mandiri, (3) aplikasi, (4) tutorial, (5) kerjasama, dan (6) evaluasi.

Dengan blended learning: Model Web centric course guru dan siswa memiliki keterampilan bahasa inggris, memiliki kemampuan mengoperasikan computer, mengenal program, software dan hardware computer, hubungan orangtua, siswa dan guru lebih transparan, dan disiplin waktu. Dengan demikian sekolah telah membentuk siswa produktif, kreatif, inovatif, dan afektif melalui penguatan sikap serta terampil yang terintegrasi untuk mengikuti pendidikan yang lebih tinggi atau untuk mencari pekerjaan.

\section{DAFTAR PUSTAKA}

Auliya Miftachul Umri, 2013, Blended Learning Dalam Pembelajaran, Bandung: PT RAJAGRAFINDO PERSADA

Jufri, Wahab A, 2010, Belajar dan Pembelajaran Sains, Mataram: Arga Puji Press

King, F.J., Goodson, L., M. S., dan Rohani, F., 2010, Higher Order Thinking Skills. Assessment dan Evaluation Educational Service Program. Journal of Interactive Learning Research, Vol 13, No 4, Hal 311-37.

Kokasih. A. L, (2010), Meningkatkan kualitas blended learning: case study menggunakan coi model, Jawa Barat.

Lim D. H, Morris M. L dan Kupritz V. W, 2005, Online vs. Blended Learning: Differences in Instructional Outcomes and Learner Satisfaction. University of Tennessee.

Leen, C.C., Hong, K.F.F.H., dan Ying, T.W, 2014, Creative and Critical Thinking in Singapore Schools. Singapore: Nanyang Technological University. 
Nasution, s. 2007. Penelitian Ilmiah.

Jakarta: Bumi Aksara

Noer, Muhammad. 2010. Blended Learning Mengubah Cara Kita Belajar Di Masa Depan. [online]. Tersedia:

http://www.muhammadnoer.co m/2010/07/blended-learningmengubah-cara-kita-belajar-dimasa-depan/. Diakses tanggal 01 Februari 2014

Prasetya Citra Sukoco. 2014. Prosiding

Seminar Nasional Profesionalisme

Tenaga Profesi Pjok. Malang: UM

Ramdhani, M.R., Usodo, B., dan Subanti, S. 2017. Discovery Learning with Scientific Approach on Geometry. Journal of Physics: Conference Series, 895. doi :10.1088/17426596/895/1/012033.

Rusman. 2011. Teknologi Informasi dan Komunikasi. Bandung: UPI

Sjukur, Sulihin B. 2012. Pengaruh Blended Learning terhadap Motivasi Belajar dan Hasil Belajar Siswa Tingkat SMK. Jurnal pendidikan Vokasi, Vol 2, Nomor 3, November 2013.

The Partnership for 21st Century Skills, 2008, 21st Century Skills, Education dan Competitiveness: A Resource and Policy Guide. Diakses 1 Desember 2015 dari http://www.p21.org/storage/docu me.
Undang-undang Nomor 14 Tahun 2015 tentang guru dan dosen: Bandung: Citra Umbara.

Uno, B. Hamzah. 2011. Model Pembelajaran. Jakarta: Bumi Aksara.

Wendhie P. 2014. Implementasi Blended Learning Dalam Pembelajaran Pada Pendidikan Dasar Dan Menengah. Yogyakarta: Widyaiswara LPMP. 